\title{
Historical Federalist Perspective On The Home Mortgage Interest Deduction For Federal Income Tax
}

Dennis S. Ortiz, University of Texas at Brownsville, USA

\begin{abstract}
This paper contributes to the on-going federal income tax debate by bringing to light the consequences of the tax laws and regulations under which our economic system operated during the post-Regan era. Specifically, this study offers a federalist perspective on one of the largest personal federal tax expenditures - the deduction for home mortgage interest (HMI). Discussion also includes background, current status, and proposed changes to the tax code for of the HMI deduction. This paper analyzes current national political rhetoric from a federalist perspective (i.e., with consideration given to the right of states to equal treatment). The distribution of the HMI deduction tax benefit between states is introduced here as a possible missing consideration in the national level political debate that dominates current discussion of the HMI deduction.
\end{abstract}

Keywords: Home mortgage interest deduction, Federal income tax, Federalist

\section{INTRODUCTION}

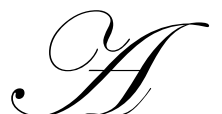

primary objective of this study is to answer the question: Is there a difference in the benefit from home mortgage interest deduction across states holding income constant? This study also investigates factors that may contribute to such differences considering the effect of a set of personal as well as a set of state characteristics on the taxpayer's HMI deduction benefit. A potentially important consequence of a difference in HMI deduction benefit across states after controlling for personal attributes of the taxpayer is that the deduction, in effect, could result in an unintended wealth transfer between states. Such a transfer would be contrary to the notion of fiscal federalism that has seen renewed public interest, primarily among conservatives led by Ronald Reagan (Williamson 1990).

Even though such interstate transfers have become almost commonplace, Federalists maintain that the national government has no business effecting resource transfers across states without good cause (such as, to protect the national interest). Based on the political unpopularity of regressive wealth transfers generally, it is further unlikely that it would be considered politically desirable, much less an important part of some national strategy, to require lower home price states (that may tend to be poorer overall) to subsidize their higher priced counterparts.

Owner-occupied housing is generally accepted as a public good. Research has shown conclusively that owner occupied housing is at least associated with socially desirable behavior. An example is that children of home owners demonstrate a higher likelihood of finishing high school and a lower likelihood of having children or of being arrested while they are teenagers (Green and White 1996 sited in Capozza et al. 1996).

The concepts and techniques applied in this study could easily be applied to other provisions of federal tax, or to any other tax system in a federation for that matter.

The rest of the paper is made up of the following sections: Section II presents a literature review, Section III discusses the methodology and results, Section IV presents the conclusions and highlight the contributions of the 
paper, and finally Section V concludes the paper.

\section{LITERATURE REVIEW}

The HMI deduction has been available to taxpayers as part of a personal interest deduction since 1913 when the 16th amendment to the U.S. Constitution first allowed for an income tax. Limits on the HMI deduction were first introduced on October 13, 1987 (P.L. 100-647). Prior to 1987 the amount of the deduction was unlimited.

One of the most serious challenges to the HMI deduction came in the early 1980s when, in fulfilling his mandate to study fundamental tax reform, President Reagan put the longstanding deduction on the table (McLure 1986). Subsequently, in a speech to the National Association of Realtors on May 10, 1984, President Reagan recanted the potential policy change, promising that his 1985 tax reform proposals "will not affect homeowner tax preferences, including the deduction for mortgage interest" (Tax Analysts 1984).

TRA '86, although not directly impacting the HMI deduction, by instituting a phase-out of the itemized deduction for consumer interest, had an important effect on the use of mortgage interest (although not reflected in the present study due to "blurring" in the data set used of information for higher income taxpayers). Having survived the Tax Reform Act of 1986 (TRA '86), the next and still today the most serious challenge to the HMI deduction comes in the form of flat tax proposals. Early versions of the flat tax were advocated by President Reagan. As the next subsection of this dissertation on the current provision demonstrates, the HMI deduction remains largely intact. The subsection after next on proposed changes in the law, however, reflects the fact that, as far as many are concerned, the HMI deduction is still "on the table."

Recently, Beland (2007) discusses the George W. Bush "ownership society" philosophy and its implications for housing policy. Zelenak (2007) notes President Bush's directly pro-housing position as expressed in creating the President's Advisory Panel on Federal Tax Reform (Executive Order No. 13,369 (2006)). In the Order, Bush mandates the Panel to recommend revenue neutral policy recognizing the "importance of homeownership.. in American society". This statement is interpreted as supporting either the HMI deduction or some similar housing subsidy. Interestingly, in the same statement, the Bush Order calls for "appropriately progressive" policy recommendations. At the same time, Fennel (2008) points out the regressive nature of the HMI deduction.

\section{HMI Provision as of 1992 and Now}

The only personal interest that is deductible today is that on debt secured by a taxpayer's primary or secondary residence. Internal Revenue Code (IRC) Paragraph 163(h)(3) sets forth the limits for the amount of such deduction: (1) interest paid or accrued on a maximum of $\$ 1,000,000$ of acquisition indebtedness, or debt otherwise grandfathered in, plus (2) interest on a maximum of $\$ 100,000$ of home equity debt (3) subject to a cap equal to the market value of the property. Interest on a home equity loan not used to buy, build or improve your home (or second home) is an AMT adjustment.

An individual whose AGI (Adjusted Gross Income) exceeds $\$ 100,000$ for tax years beginning after December 31, 1990 (indexed for inflation, $\$ 105,250$ for 1992, $\$ 166,800$ for 2009) is required to reduce the amount of allowable itemized deductions by $3 \%$ of the excess of AGI over $\$ 100,000$ (for 1991, the first year in which IRC Section 68 took effect providing for the phase out of itemized deductions for higher income taxpayers). The reduction cannot exceed $80 \%$ of otherwise allowable deductions (excluding deductible medical expenses, investment interest, casualty, theft, and wagering losses). No reduction is required in the case of medical, investment interest, casualty, theft, and wagering losses.

\section{METHODOLOGY}

There are two main parts to the empirical analysis. First, a Tobit regression is used to analyze the distribution of the home mortgage interest (HMI) tax benefit across states and to test for disproportionate 
distribution across states. The focus of this first part of the study is on answering the question of whether there is a difference between states in terms of the benefit derived from the federal income tax deduction for home mortgage interest beyond that which is explained by income. This initial part of the study is the precursor to a hierarchical analysis seeking to identify significant factors affecting the distribution of the benefit of the HMI deduction across states. The primary data source is the Ernst and Young/University of Michigan Individual Model File of 1992 tax returns.

The second part of the analysis examines the effect of sets of factors in a causal hierarchy on the HMI deduction benefit. By first controlling for the effects of personal and identifiable state characteristics on HMI deduction benefit, the possible existence of a residual socio-political force is tested. The primary data sources are the 1990 Census of Population and Housing (U.S. Department of Commerce 1993) 5\% Public Use Microsample as well as 1989 tax data extracted from the Statistics of Income, Individual Public Use Tax File, Level III Sample. Other sources include the Federal Housing Finance Board, Mortgage Bankers of America, U.S. Department of Housing and Urban Development, and Bureau of Census, Statistical Abstracts. Hypothesis testing is conducted with the use of a Ridge regression analysis.

\section{Policy Recommendations}

Although the purpose of this study is not to analyze the possible effects of policy proposals in this area of the income tax, this subsection discusses proposals to cure the distributional problems with the HMI deduction. Special emphasis is given to the idea of indexing to account for interstate disparities.

\section{Proposed Changes Regarding Home Mortgage Interest}

Recent attention paid to federal tax expenditures including the HMI deduction is understandable given the problem of the size of the national debt. Proposed changes to the current IRC provisions regarding the HMI deduction include: (1) eliminating the deduction altogether (Hall 1987; Representative Armey's Freedom and Fairness Restoration Act of 1994. 103d Congress. June 16, 1994. H.R. 4585; Congressional Budget Office (CBO) see Tax Analysts 1994), (2) reducing the cap on the amount of deduction allowed to interest on the first $\$ 500,000^{1}$, or $\$ 300,000$ of debt (Tax Analysts 1995a, see CBO analysis in Tax Analysts 1994, 1995b and $\mathrm{c}^{2}$ ), or the first $\$ 100,000$ of mortgage debt (as proposed by Sen. Arlen Specter, R-Pa, see Tax Foundation 1995), or similarly, the first $\$ 12,000$ of interest paid (Hall 1987 and Tax Analysts 1995c ${ }^{3}$ ), (3) replacing the present deduction with a credit (Hall 1987; Luttman 1988, Luttman \& Spindle 1994 suggesting replacement of all itemized deductions with a single credit), (4) providing some form of rental deduction or credit (Hall 1987), (5) providing a general housing deduction or credit (Hall 1987), (6) eliminating or limiting the deduction for second homes (Tax Analysts 1993, see CBO proposal in Tax Analysts 1995b and 1995c), (7) taxation of rental value of the home as income under Simpson's definition of income (Pechman 1989), (8) Universal Renter-to-Homeowner Credit (Covington \& Harrell 2007), and finally, (9) indexing. Other possibilities enumerated by America's Community Bankers et al. (1995) (most of which are also evaluated by $\mathrm{CBO}$ ) include limiting the benefit of itemized deductions to 15 percent, as well as including

\footnotetext{
1 In commenting on the Clinton economic proposal, members of congress voiced concern over possible changes in the HMI deduction. (Tax Analysts 1993)

2 Johnston (1996) reports that in response to (then Republican Senator from Oregon and chairman of the Senate Finance Committee) Robert Packwood's early 1996 proposal to limit the mortgage interest deduction to interest on the first $\$ 300,000$ of mortgage debt, the home builders' association expressed concern that the cut "would fall hardest on California, New York, New Jersey, Connecticut, Maryland, Virginia and Florida because they have three-fourths of all homes valued at $\$ 250,000$ or more." America's Community Bankers et al. (1995) similarly reply to the same proposed $\$ 300,000$ cap on eligible debt, that such a policy "would be unequally distributed across the nation, with high-cost housing locations such as Hawaii and California and parts of the Northeast experiencing major home price declines. Moreover, if the proposal is adopted without an indexation provision, the share of homes affected will increase over time as home prices rise."

During his failed campaign for the 1996 Republican presidential nomination, Senator Arlen Specter of Pennsylvania suggested not allowing a deduction on mortgage balances above $\$ 100,000$.

${ }^{3}$ CBO proposal recommends capping the mortgage interest deduction at $\$ 12,000$ per single return, $\$ 20,000$ per joint return. Also, the final report of the Bipartisan Commission on Entitlement and Tax Reform, chaired by J. Robert Kerrey included a recommendation to phase in HMI deduction limits between 1995 and 2000 (Tax Analysts 1995a).
} 
mortgage interest deduction amounts in the calculation of the alternative minimum tax, and replacing itemized deductions with a consumption tax. Finally, the "USA Tax System" plan of Sens. Pete V. Domenici, R-N.M., and Sam Nunn, D-Ga., retains the deduction entirely (Tax foundation 1995).

Republicans running for their party's nomination in the 1996 presidential race were divided on the mortgage-interest deduction. Malcolm S. Forbes Jr. wanted to eliminate it; Patrick Buchanan wanted to keep it, and Senators Bob Dole and Phil Gramm avoided a hard position. Astute observers have noted that any radical change in the HMI deduction would probably require some transition. One proposed plan would be to grandfather those who already have mortgages, letting them deduct mortgage interest until they sell their homes or refinance; another possibility would be to phase out the deduction, say at 10 percent a year for a decade. Further, one problem with a phase-out is that people with adjustable rate mortgages might see their interest rates fall and reap the benefit of lower rates and a tax deduction.

Finally, although analysis is beyond the scope of the present research, this dissertation proposes that an indexation scheme associated with a lower cap, as alluded to by America's Community Bankers et al. (1995) be added to the list of proposed options.

With regard to suggested lowering of the cap on mortgage loans eligible for deduction from the current $\$ 1$ million, when you begin considering lowering the cap on the HMI deduction you run into the problem of finding a cap that is equitable across states, as lowering the cap on regular mortgages could create significant regional disparities due to the wide range of housing costs. It is interesting to note that cross-location variation in home price is less for lower income households (i.e., most of the variation in average home price probably comes from differences on the upper end of the scale (Weinstein, 1979)). The idea of indexing a cap has precedent in U.S. tax policy (see Kenyon and Kincaid (1991) for detailed discussion of the effects of indexing applied to tax exemption of interest on state and local borrowing). Fennell (2007) discusses use of local housing market indexing (providing examples) in the context of housing risk sharing. Analysis of such a policy proposal (i.e., an indexed cap on deductible HMI) should be the subject of future research.

Indexing to achieve tax equity objectives has actually taken on two forms (1) the type of cross-sectional indexing as applied to municipal bond interest (IRC Sec. 103) (discussed above), as well as in the context of federal grants-in-aid (discussed elsewhere in this dissertation), and (2) inflation indexing to account for changes in living costs across time. The second type of indexing is applied to personal income tax brackets other than the 36\% bracket and 39.6\% bracket (that does not apply until 1993 and later tax years. See IRC Sec. 1(f)), the standard deduction (IRC Sec. 1(f)), the personal exemption (IRC Sec. 151(1)(d)), and the earned income credit (IRC Sec. 32(i)). Although accounting for inflation is certainly possible, cross-sectional (cross-state) indexing is of particular interest in the context of a dramatically lowered HMI deduction cap.

\section{CONCLUSIONS AND CONTRIBUTIONS}

\section{Conclusions}

The primary conclusion to be drawn from this study is that there is a significant amount of variation between residents of different states in the HMI deduction benefit realized in 1992. This variation persists even after removing the effect of income on the HMI tax benefit. This conclusion is the basis for the second part of the study investigating state characteristics which could explain the state-to-state differences. This part of the analysis reveals that even after parceling out the effects of personal characteristics of the head of household, a set of state characteristics possesses significant explanatory power in terms of household HMI deduction tax benefit. Finally, after factoring out both personal as well as the defined set of state characteristics, there still remains a significant difference in HMI deduction benefit between states. This difference may is hypothesized to be attributable to sociopolitical differences between states which are not captured in the present model. Future research should attempt to narrow down the state-to-state differences causing this residual, unexplained variation in HMI deduction tax benefit. 


\section{Contributions}

This study extends existing research in the following areas: (1) distributional analysis of the effects of Federal Income Taxation, (2) fiscal federalism and competition between states, and (3) determinants of mortgage borrowing choice, with implications for housing and tenure choice. Further, this study attempts to bridge the gap between these areas.

To the extent that other nations are formed by the unification of heterogeneous states, the issue of federalism is important. To the extent that fiscal federalism exists as a policy objective in the United States, this study may have important implications for domestic income tax policy. For other jurisdictions, the less cohesive the political union (i.e. the less people feel they belong to the same group), the more important the distributional consequences of federal tax policies such as the HMI deduction are likely to be. In other words, the less people feel they will benefit from being part of a particular group (for example, the United States), the less willing they are to share with other members of the group. In such a case it is natural that concern will increase whenever there is a perception that resources are being involuntarily appropriated and transferred to an outside group (for example, the citizens of another state).

At a minimum, this study offers a national analysis of state-to-state differences in a major tax provision. The study also allows for variation across households and states of certain potentially significant causal variables. These variables include a set of personal characteristics of the head of household as well as a set of characteristics of the state. The concepts and techniques applied in this study could easily be applied to other provisions of federal tax, as well as to the possibly differential effects of state tax provisions on residents of various localities within the state. Finally, the methodology employed in this study may be transferred to the exploration of tax settings of other federations. It is hoped that by highlighting this federalist aspect of the HMI deduction benefit distribution, this work sheds new light on the consequences of this tax provision as well as others.

\section{FUTURE RESEARCH}

A possible extension of this study would be to actually simulate (on a static basis) the effect of indexing (based on housing cost in each state) on the distribution of the HMI deduction. Once identified, key characteristics of each state should be analyzed to determine which are significant in determining the amount of HMI deduction necessary to equalize federal subsidy across states. Next, these key factors could be used to compute an index that, when applied to the HMI deduction, adjusts for key factors causing differences between states. Several approaches to implementing such an equalization scheme including a cap on the deduction which might vary by state.

\section{AUTHOR INFORMATION}

Dr. Dennis Ortiz received his B.Sc. and Masters in accounting degrees from the University of Arizona and Ph.D. in accounting from the University of North Texas. He is also holds a Texas CPA license. He worked as a tax consultant for Deloitte and Touche, and Clifton Gunderson. He also worked for IBM Data Processing Division, and Nixdorf Computer. Currently, he teaches tax accounting, information systems, ethics and financial accounting at the University of Texas at Brownsville, and his research interests are: tax equity, business ethics, attributes of corporate governance, determinants of CPA exam passing rates, Activity-Based Costing, and accounting and financial analysis of sports industry.

\section{REFERENCES}

1. America's Community Bankers, American Bankers Association, Mortgage Bankers Association, National Association of Home Builders, and National Association of Realtors. March, 1995. The impact of potential policy changes affecting the mortgage interest deduction on the housing and financial sectors. A staff white paper. Washington, D.C.

2. Béland, D. (2007). Neo-liberalism and social policy. Policy Studies, 28(2), 91-107. 
3. Capozza, D. R., R. K. Green, and P. H. Hendershot. 1996. Taxes, mortgage borrowing, and residential land prices. In Economic effects of fundamental tax reform. Edited by Henry J. Aaron and William G. Gale. Washington, D.C.: Brookings Institution Press.

4. Covington, K., \& Harrell, R. (2007). From renting to homeownership: Using tax incentives to encourage homeownership among renters. Harvard Journal on Legislation, 44(1), 97-117.

5. Hall, B. J. P. 1987. An Analysis of the Equity and Revenue Effects of the Elimination or Reduction of Homeowner Preferences. Unpublished dissertation. University of North Texas, Denton.

6. $\quad$ Executive Order 13369, 3 C.F.R. 155 (2006).

7. Fennell, L. A. (2008). Homeownership 2.0. Northwestern University Law Review, 102(3), 1047-1118.

8. $\quad$ Freedom and Fairness Restoration Act of 1994. 103d Congress. June 16, 1994. H.R. 4585.

9. Johnston, D. C. 1996. The divine write-off; republicans tiptoe around the mortgage deduction. The New York Times. Section D; Page 1; Column 2; Business/Financial Desk. Friday, January 12, Late Edition.

10. Kenyon, D. A. and J. Kincaid. 1991. Introduction. by Kenyon, Daphne A. and John Kincaid eds. Competition Among States and Local Governments: Efficiency and Equity in American Federalism. Washington, D.C.: The Urban Institute Press: 1-34.

11. Luttman, S. M. 1988. The distributional and labor supply effects of alternative individual income tax proposals. Unpublished dissertation. University of Illinois at Urbana-Champaign.

12. Luttman, S. M. and R. Spindle. 1994. An evaluation of the revenue and equity effects of converting exemptions and itemized deductions to a single non-refundable credit. The Journal of the American Taxation Association. 16 (Fall): 43-62.

13. McLure, C. E. Jr. 1986. The tax treatment of owner-occupied housing: the Achilles' heel of tax reform? in Tax Reform and Real Estate. ed by James R. Follain. Washington, D.C.: The Urban Institute Press: 219232.

14. Pechman, J. 1989. Tax reform, the Rich and the Poor, second edition. Washington, D.C.: The Brookings Institution.

15. Tax Analysts. 1984. Reagan promises no change in homeowner tax benefits. Tax Notes Today (May 11) Today's Tax Highlights.

16. Tax Analysts. 1993. Members of congress voice opinions on Clinton economic proposal. Tax Notes Today 93 (February 26): 46-91.

17. Tax Analysts. 1994. CBO outlines 36 tax hike ideas. Tax Notes Today 94 (March 1): 55-13.

18. Tax Analysts. 1995a. Bipartisan reform commission releases final report. Tax Notes Today 95 (February 17): 33-43.

19. Tax Analysts. 1995b. Unofficial transcript of March 2 finance hearing on middle-income tax proposals. Tax Notes Today 95 (March 2): 49-107.

20. Tax Analysts. 1995c. Congressional budget office releases deficit reduction book; discusses international tax proposals. Tax Notes International (March 7): Doc. 95-2582.

21. Tax Foundation. 1995. Tax foundation presents mortgage interest deduction. Tax Notes Today (May 16)

22. U.S. Department of Commerce. 1993. 1990 Census of Population and Housing, Public Use Microdata Samples, United States, Technical Documentation. U.S. Department of Commerce: Washington D.C.

23. Weinstein, B. L. 1979. Cost of Living Adjustments for Federal Grants-in-aid: a Negative View. Southern Growth Policy Board.

24. Williamson, R. S. 1990. Reagan's Federalism: His Efforts to Decentralize the Government. N.Y.: University Press of America.

25. Zelenak, L. (2007). The theory and practice of tax reform. Michigan Law Review, 105(6), 1133-1149. 